\title{
Pengujian Karakteristik Campuran AC-BC Yang Menggunakan Batu Gunung Baba, Tana Toraja
}

\author{
James Alfrian ${ }^{* 1}$, Alpius ${ }^{\star 2}$, Louise Elizabeth Radjawane*3 \\ *1 Mahasiswa Program Studi Teknik Sipil, Universitas Kristen Indonesia Paulus, Makassar \\ Email jamesalfrian99@gmail.com \\ *2 Dosen Program Studi Teknik Sipil, Universitas Kristen Indonesia Paulus, Makassar \\ Email alpiusnini@gmail.com \\ *3 Dosen Program Studi Teknik Sipil, Universitas Kristen Indonesia Paulus, Makassar \\ Email eliz louise@yahoo.com
}

\begin{abstract}
ABSTRAK
Penelitian ini memanfaatkan Batu Gunung Baba untuk diketahui karakteristik agregat dari Batu Gunung Baba Kabupaten Tana Toraja Dalam Campuran AC-BC. Metode dalam penelitian ini adalah melakukan serangkaian pengujian karakteristik agregat kasar, halus, dan filler kemudian merancang komposisi campuran AC-BC serta pengujian Marshall untuk mendapatkan karakteristik campuran dan pengujian Marshall Immersion untuk memperoleh Stabilitas Marshall Sisa campuran berkadar aspal optimum. Hasil penelitian menunjukkan bahwa karakteristik bahan perkerasan berupa batu Gunung Baba Kabupaten Tana Toraja memenuhi spesifikasi sebagai bahan lapisan perkerasan jalan. Melalui Uji Marshall diperoleh karakteristik campuran AC-BC dengan kadar aspal 5,0\%, 5,50 \%, 6,0 \%, 6,50 \%, 7,0 \%. Hasil pengujian Marshall Immersion campuran AC-BC dengan kadar aspal optimum 5,50\% diperoleh Stabilitas Marshall Sisa sebesar 96,47\% memenuhi Spesifikasi Bina Marga Tahun 2018 yaitu minimal $90 \%$.
\end{abstract}

Kata Kunci : Karakteristik agregat, Komposisi LASTON AC-BC, Uji Marshall

\begin{abstract}
This study was intended to determine the aggregate characteristics of the Batu Gunung Baba Tana Toraja Regency in the $\mathrm{AC}-\mathrm{BC}$ mixture. The method is to conduct a series of characteristic tests for coarse, fine, and filler aggregates then design the composition of the AC-BC mixture and Marshall test to obtain the characteristics of the mixture and test the Marshall Immersion to obtain Marshall Stability The optimum residual bitumen content mixture. The results showed that the characteristics of the pavement material in the form of Mount Baba stone met the specifications as a road pavement coating material. Through the Marshall test, the characteristics of the AC-BC mixture were obtained with asphalt content of $5.0 \%$, $5.50 \%, 6.0 \%, 6.50 \%, 7.0 \%$. The results of Marshall Immersion test for AC-BC mixture with optimum asphalt content of $5.50 \%$, obtained the remaining Marshall Stability of $96.47 \%$ fulfilling the 2018 Highways Specification, which is at least $90 \%$.
\end{abstract}

Keywords: Aggregate Characteristics, LASTON AC-BC Composition, Marshall Test

\section{PENDAHULUAN}

Pada umumnya jenis tanah dapat dibedakan menjadi Perkembangan konstruksi jalan raya di Indonesia dari waktu ke waktu terus meningkat. Peningkatan tersebut khususnya pada lapisan permukaan, dimana semakin bagus perkerasan jalan maka akan semakin mudah pergerakan kendaraan dan lalu lintas akan berjalan lancar. Kestabilan dari konstruksi perkerasan jalan raya ditentukan oleh mutu material, komposisi campuran serta cara pelaksanaan pekerjaan. Di Indonesia, sebagian besar konstruksi jalan raya menggunakan tipe perkerasan lentur dengan aspal minyak sebagai bahan pengikat dan agregat serta filler atau pengisi campuran aspal. Gunung Baba adalah gunung yang terletak di
Lembang Rano Utara Kecamatan Rano Kabupaten Tana Toraja Provinsi Sulawesi Selatan yang merupakan kawasan Industri penghasil batu kapur. Gunung ini memiliki bahan material yang cukup memadai utamanya dalam pembangunan prasarana transportasi di sekitar daerah tersebut. Batu gunung ini banyak digunakan sebagai konstruksi pondasi karena struktur dan wujudnya yang kokoh serta tidak muda hancur. Untuk mengetahui karakteristik agregat dari batu Gunung Baba, karakteristik aspal dan berat jenis filler untuk campuran AC $B C$, mengetahui komposisi campuran AC - BC (Asphalt Concrete - Binder Course) yang menggunakan agregat Gunung Baba, dan Mengetahui karakteristik dan nilai Stabilitas Marshall sisa campuran AC - BC dari agregat 
Gunung Baba Kabupaten Tana Toraja melalui pengujian Marshall.

Abu bata ringan yang lolos saringan 200 dapat digunakan sebagai campuran pada laston AC-WC [1], nilai marshall immersion menggunakan agregat Sungai Bittuang 95,03\% dapat digunakan dalam campuran AC-WC [2], nilai kadar aspal optimum dari agregat Sungai Mawa untuk laston AC-WC sebesar $7 \%$ dan indeks perendaman 94,81\% [3], penambahan serat aren menurunkan daya tahan campuran terhadap perendaman [4], batu Sungai Lamasi dapat digunakan sebagai bahan campuran lapisan AC-WC karena memenuhi spesifikasi Bina Marga 2018 [5], nilai stabilitas pada campuran laston AC-WC akan mengalami peningkatan seiring dengan penambahan Aspal Buton sebagai filler [6]. Nilai stabilitas tertinggi $1571,37 \mathrm{~kg}$ untuk kadar plastik $2 \%$ [7], penggunaan agregat batu Sungai Tiakka dengan kadar aspal optimum 7\% menghasilkan nilai indeks kekuatan sisa 93,47\% [8], penggunaan fly ash pada campuran $\mathrm{AC}-\mathrm{BC}$ meningkatkan nilai $\mathrm{MQ}$, namun menurunkan nilai kelelehan [9], penggunaan kadar aspal 5\% untuk campuran AC-BC memiliki kemampuan mencegah keausan, tidak mudah retak, dan deformasi tinggi [10].

\section{METODE}

Lokasi tempat pengambilan material diambil dari Gunung Baba yang berjarak \pm 200 meter dari Kantor Lembang Rano Utara. Di sebelah barat terdapat Gereja Toraja Jemaat Golguta Puru sekitar \pm 500 meter dari lokasi. Lokasi penelitian dapat dilihat pada gambar 1

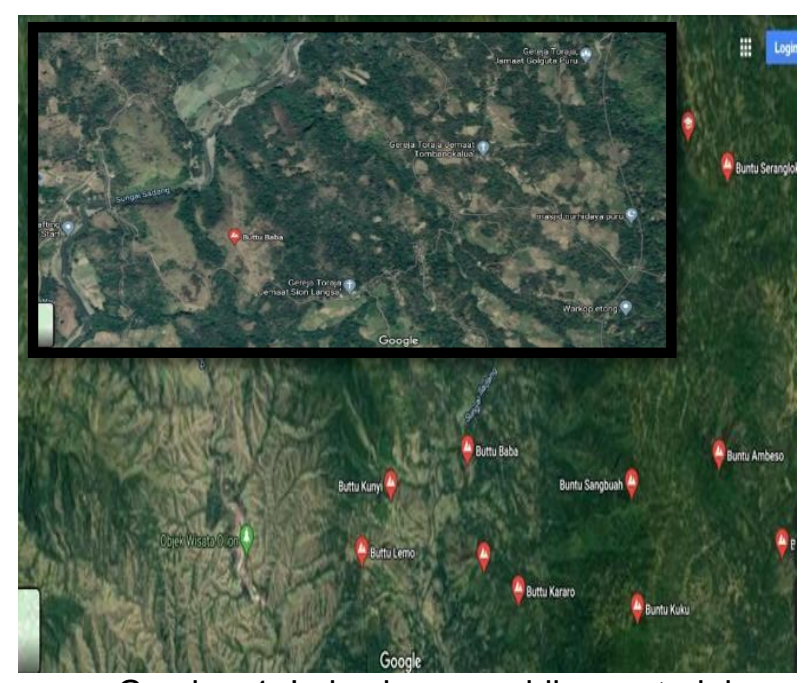

Gambar 1. Lokasi pengambilan material

\section{Pemeriksaan Karakteristik Agregat}

Analisa Saringan (SNI ASTM C136:2012). Pemeriksaan terhadap analisa saringan dimaksudkan untuk menentukan pembagian butir (gradasi) agregat dengan menggunakan saringan.
Tujuan pengujian ini untuk memperoleh besaran atau jumlah presentase butiran.

Pemeriksaan Berat Jenis Curah (Bulk) dan Penyerapan Air Agregat Kasar (SNI 1969:2016) dan Penyerapan Agregat Halus) SNI 1970:2016). Pemeriksaan ini untuk menentukan berat jenis curah, berat jenis permukaan jenuh, berat jenis semu dari agregat, serta angka penyerapan dari agregat.

Pemeriksaan Nilai Setara Pasir (SNI 03-4428-1997). Maksud dari pemeriksaan ini yaitu untuk mengetahui tingkat kadar presentase kadar lumpur yang terkandung dalam suatu agregat.

Pemeriksaan Keausan Agregat (SNI 2417:2008). Pemeriksaan ini dimaksudkan untuk menentukan ketahanan agregat terhadap keausan dengan menggunakan mesin abrasi Los Angeles. Pengujian ini adalah untuk mengetahui angka keausan tersebut, yang dinyatakan dengan perbandingan antara berat bahan aus lolos saringan No.12 $(0,075 \mathrm{~mm})$ terhadap berat semula.

Pemeriksaan Partikel Pipih dan Lonjong (ASTM D4791-10). Pemeriksaan ini bertujuan untuk menguji keseragaman agregat. Bentuk butiran agregat adalah ukuran normal dari sebuah agregat dimana ukuran nominal ini bergantung kepada besar ukuran agregat dominan pada suatu gradasi tertentu.

Pemeriksaan Kelekatan Agregat Pada Aspal (SNI 2439: 2011). Pemeriksaan ini bertujuan untuk menentukan kelekatan agregat terhadap aspal. Kelekatan agregat terhadap aspal ialah presentase luas permukaan batuan yang tertutup aspal terhadap keseluruhan luas permukaan.

Pemeriksaan Agregat Lolos Ayakan No.200 (SNI ASTM C117: 2012). Maksud pemeriksaan yaitu bertujuan untuk mengukur persentase jumlah bahan dalam agregat yang lolos saringan 200 sehingga berguna bagi perencana dan pelaksana pembangunan jalan.

\section{Pemeriksaan Karakteristik Aspal}

Pemeriksaan Penetrasi pada $25^{\circ} \mathrm{C}$ (SNI 2456:2011). Maksud dari pengujian ini ialah mendapatkan nilai kekerasan aspal dengan melakukan pengujian penetrasi menggunakan alat penetrometer.

Pengujian Daktilitas (SNI 2432:2011). Maksud pemeriksaan ini adalah mengetahui kekenyalan/keplastisan aspal yang dinyatakan dengan panjang pelumaran aspal yang dapat dicapai aspal sebelum putus, pada suhu dan kecepatan tertentu.

Pengujian Titik Lembek Aspal (SNI 2434:2011). Maksud dari pemeriksaan ini ialah mengetahui suhu dimana aspal mulai lembek dengan menggunakan 
alat ring and ball dimana suhu ini akan menjadi acuan dilapangan atas kemampuan aspal menahan suhu yang terjadi agar tidak lembek sehingga dapat mengurangi daya lekat.

Pengujian Titik Nyala $\left({ }^{\circ} \mathrm{C}\right.$ ) (SNI 2433:2011). Maksud dari pemeriksaan ini ialah mengetahui suhu dimana aspal mulai dapat mengeluarkan nyala dan terbakar akibat pemanasan.

Pengujian Berat Jenis Aspal (SNI 2441:2011). Pemeriksaan ini bertujuan untuk mengetahui berat jenis aspal yang digunakan. Dimana berat jenis aspal merupakan perbandingan antara berat bitumen atau ter terhadap air suling dengan isi yang sama pada suhu tertentu.

Pemeriksaan Berat Yang Hilang (\%) (SNI-06-24411991). Maksud pengujian untuk mengetahui kehilangan berat pada aspal akibat pemanasan yang berulang dan pengujian ini juga bertujuan untuk mengukur perubahan kinerja aspal akibat kehilangan berat.

Penetrasi pada $25{ }^{\circ} \mathrm{C}$ TFOT (SNI 2456:2011). Maksud dari pengujian ini adalah mendapatkan nilai kekerasan aspal yang telah mengalami pemanasan dengan alat Thin Flim Oven Test dengan melakukan pengujian penetrasi menggunakan alat penetrometer, dimana pengujian ini akan menjadi acuan penggunaan aspal di lapangan.

\section{Pemeriksaan Berat Jenis Filler}

Pemeriksaan berat jenis filler mengacu pada standar rujukan SNI ASTM C136:2012. Maksud dari pengujian ini ialah dapat menentukan berat jenis filler yang akan digunakan sebagai bahan pengisi campuran aspal.

\section{Rancangan Komposisi Campuran}

Komposisi campuran yang digunakan dalam penelitian ini adalah gradasi yang berdasarkan pada Direktorat Jendral Bina Marga. Campuran aspal panas (Hot mix) yang terdiri dari komponenkomponen agregat yang merupakan komponen terbesar dalam campuran digunakan sebagai komposisi campuran AC-BC. Komposisi campuran didasarkan pada gradasi campuran agregat dalam yang dipilih yaitu gradasi ideal atau menggunakan nilai tengah dari rentang gradasi yang digunakan. Komposisi campuran agregat dibagi menjadi tiga fraksi yaitu fraksi agregat kasar, fraksi agregat halus, dan fraksi bahan pengisi. Dimana ukuran dari fraksi didasarkan pada Spesifikasi Umum Bina Marga 2018 Divisi 6.

Tabel 1. Rancangan komposisi campuran

\begin{tabular}{cccc}
\hline & & \multicolumn{2}{c}{$\begin{array}{c}\text { \% Berat Yang Lolos Terhadap Total Agregat dalam } \\
\text { Campuran AC-BC }\end{array}$} \\
\cline { 2 - 4 } Nomor Saringan & $\begin{array}{c}\text { Ukuan Ayakn } \\
(\mathrm{mm})\end{array}$ & 100 & $\begin{array}{c}\text { Rancangan Gradasi } \\
\text { Campuran }\end{array}$ \\
\hline $11 / 2$ & 37,5 & $90-100$ & 100 \\
1 & 25 & $75-90$ & 95,5 \\
$3 / 4$ & 19 & $66-82$ & 82,5 \\
$1 / 2$ & 12,5 & $46-64$ & 74,0 \\
$3 / 8$ & 9,5 & $30-49$ & 55,0 \\
No. 4 & 4,75 & $18-38$ & 39,5 \\
No. 8 & 2,36 & $12-28$ & 28,0 \\
No. 16 & 1,18 & $7-20$ & 20,0 \\
No. 30 & 0,6 & $5-13$ & 13,5 \\
No. 50 & 0,3 & $4-8$ & 9,0 \\
No. 100 & 0,15 & & 6,0 \\
No. 200 & 0,075 & & \\
\hline
\end{tabular}

\section{Pengujian Marshall Konvensional}

Ada tiga tahap pengujian yang dilakukan dari metode Marshall Konvensional yaitu melakukan pengukuran berat jenis, pengukuran stabilitas dan flow serta pengukuran kerapatan dan analisa rongga. Sebelum dilakukan pengujian benda uji, perlu dilakukan hal-hal sebagai berikut:

a. Benda uji harus bersih dari kotoran organik, minyak, kertas dan sebagainya. b. Setiap benda uji diberi tanda pengenal yang mencirikan jumlah variasi yang diberikan.

c. Mengukur tinggi masing-masing benda uji dengan menggunakan jangka sorong dengan ketelitian $0,1 \mathrm{~mm}$. Tinggi benda uji adalah rata-rata tiga kali pengukuran.

\section{Penentuan Kadar Aspal Optimum}

Setelah melakukan pengujian Marshall Konvensional maka dilakukan perhitungan untuk mendapatkan 
Kadar Aspal Optimum. Data-data yang telah didapatkan diolah dan dimasukkan ke dalam tabel data Hot Mix Desain metode Marshall maka akan didapatkan nilai hasil stabilitas, flow, VIM, VMA, VFB. Kadar aspal optimum didapatkan dari nilai rataan terendah dari grafik hubungan VIM (Void In Mix), campuran yang dipadatkan dengan kadar aspal. Kadar aspal praktis dalam campuran beton aspal yaitu kadar aspal yang memenuhi semua kriteria atau karakteristik.

Berdasarkan fungsi campuran AC-BC stabilitas merupakan kemampuan lapis perkerasan menerima beban lalu lintas tanpa mengalami perubahan bentuk tetap seperti gelombang, alur (rutting), maupun mengalami bleeding, nilai stabilitas dipengaruhi oleh kohesi/penetrasi, kadar aspal, gesekan (internal Friction), sifat saling mengunci (interlocking) dari partikel-partikel agregat, bentuk, tekstur permukaan serta gradasi agregat.

\section{Pengujian Marshall Immersion}

Pengujian Marshall Immersion mengacu pada SNI 06-2489-1991. Pengujian ini bertujuan untuk mengetahui kemampuan campuran terhadap lama perendaman, suhu, dan air.

\section{HASIL DAN PEMBAHASAN}

\section{Karakteristik Bahan}

\section{Karakteristik Agregat}

Hasil pengujian keausan agregat dengan menggunakan Alat Abrasi Los Angeles diperoleh nilai ketahanan agregat kasar terhadap keausan dari Fraksi A adalah $20,8 \%$, Fraksi B adalah $22,56 \%$, Fraksi C adalah $13,52 \%$ dan Fraksi D adalah 21,04 $\%$. Dari semua hasil pengujian, tiap fraksi memenuhi Spesifikasi Umum Bina Marga 2018 yaitu dengan nilai maksimum 40\%. Sehingga dapat diketahui bahwa agregat dari Gunung Baba Kecamatan Rano yang digunakan sebagai bahan lapisan permukaan jalan dapat tahan terhadap keausan akibat gesekan antara agregat.

Hasil pengujian berat jenis dan penyerapan agregat kasar yang menggunakan dua sampel diperoleh nilai untuk Berat Jenis Bulk adalah 2,54\% berat jenis SSD adalah $2,57 \%$ berat jenis semu adalah $2,61 \%$ dan Penyerapan Air adalah 0,96\%. Semua hasil pengujian memenuhi Spesifikasi Umum Bina Marga 2018 yaitu untuk Berat Jenis Bulk, Berat Jenis SSD dan Berat Jenis Semu adalah minimal 2,5\% dan Penyerapan Air maksimal 3\% atau dapat dikatakan bahwa penyerapan agregatnya sedang. Berdasarkan hasil pengujian Berat Jenis dan Penyerapan Agregat Halus diperoleh nilai untuk Berat Jenis Bulk adalah 2,55\%, Berat
Jenis SSD adalah 2,58\%, Berat Jenis Semu adalah $2,62 \%$ dan Penyerapan Air adalah 0,91\%. Semua hasil pengujian memenuhi Spesifikasi Umum Bina Marga 2018 yaitu untuk Berat Jenis Bulk, Berat Jenis, Berat Jenis Semu adalah minimal 2,5\% dan Penyerapan Air maksimal adalah 3\%.

Hasil analisa saringan berupa gradasi agregat serta spesifikasinya dimana gradasi agregat berada mendekati batas atas, ini menunjukkan bahwa agregat dari Gunung Baba Kabupaten Tana Toraja yang dipakai banyak mengandung gradasi halus tetapi masih memenuhi Spesifikasi Umum Bina Marga 2018.

Dari hasil pengujian material lolos saringan No.200 diperoleh hasil $7,80 \%$ sehingga memenuhi Spesifikasi Umum Bina Marga 2018 yaitu maksimal $10 \%$. Hasil pengujian . Nilai Setara Pasir dimana dari hasil pengujian nilai setara pasir diperoleh hasil rata-rata untuk nilai Sand Equivalent (SE) adalah $97,76 \%$ dan nilai setara pasir $2,24 \%$. Keduanya memenuhi Spesifikasi Umum Bina Marga 2018 yaitu minimal 50\% untuk Sand Equivalent dan maksimal 5\% untuk nilai setara pasir. Dapat diketahui bahwa agregat dari Gunung Baba Kecamatan Rano memiliki nilai setara pasir yang cukup tinggi.

Hasil pengujian analisa saringan dapat dilihat pada gambar 2.

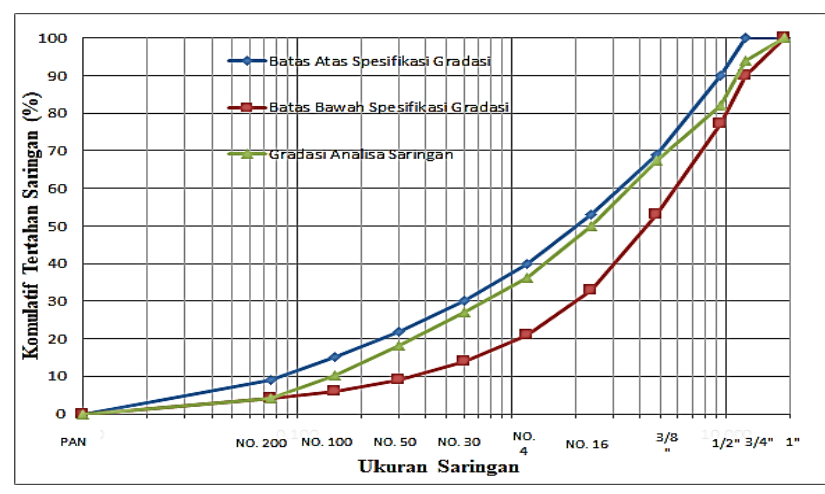

Gambar 2. Hasil pengujian analisa saringan

Hasil Pengujian Partikel Pipih dan Lonjong agregat kasar diperoleh partikel pipih yaitu $7,77 \%$, $4,71 \%, 3,48 \%$, dan $0,00 \%$. Dan partikel lonjong yaitu $3,95 \%, 5,53 \%, 5,61 \%$ dan $0 \%$. Kedua nilai tersebut telah memenuhi Spesifikas Umum Bina Marga 2018 yaitu maksimal $10 \%$. Dari hasil pengujian Kelekatan Agregat Terhadap Aspal diperoleh nilai sebesar 98,00\% dimana memenuhi Spesifikasi Umum Bina Marga 2018 yaitu minimum 95\%.

Karakteristik Aspal 
Aspal yang digunakan dalam penelitian ini untuk pembuatan campuran AC-WC adalah aspal minyak penetrasi 60/70.

Hasil untuk nilai penetrasi adalah $66,7 \mathrm{~mm}$. Hasil pengujian telah memenuhi Spesifikasi Umum Bina Marga 2018 yaitu minimal $60(0,1 \mathrm{~mm})$ - maksimum $70(0,1 \mathrm{~mm})$ untuk nilai penetrasi aspal.

Hasil pengujian daktilitas didapatkan nilai rata-rata $150 \mathrm{~cm}$. Hasil ini masuk dalam syarat yang ditentukan dalam spesifikasi Umum Bina Marga 2018 yaitu $\geq 100$ $\mathrm{cm}$.

Hasil pengujian titik lembek aspal didapatkan nilai rata-rata $50.2^{\circ} \mathrm{C}$. Hasil ini masuk dalam syarat yang ditentukan dalam spesifikasi Umum Bina Marga 2018 yaitu $\geq 48^{\circ} \mathrm{C}$.
Hasil pengujian titik nyala didapatkan nilai rata-rata $240^{\circ} \mathrm{C}$. Hasil ini masuk dalam syarat yang ditentukan dalam spesifikasi Umum Bina Marga 2018 yaitu $\geq$ $232^{\circ} \mathrm{C}$.

Hasil pengujian berat jenis aspal didapatkan nilai rata-rata 1.015 . Hasil ini masuk dalam syarat yang ditentukan dalam Spesifikasi Umum Bina Marga 2018 yaitu $\geq 1$.

Hasil pengujian berat yang hilang didapatkan nilai rata-rata $0.434 \%$. Hasil ini masuk dalam Spesifikasi Umum Bina Marga 2018 yaitu $\geq 0.8 \%$ dalam syarat yang ditentukan.

Hasil pengujian penetrasi pada Thin Flim Oven Test didapatkan nilai rata-rata $84,7 \%$. Hasil ini masuk dalam syarat yang ditentukan dalam spesifikasi Umum Bina Marga 2018 yaitu $\geq 54 \%$ dari penetrasi sebelum kehilangan berat.

Tabel 2. Tabel komposisi campuran

\begin{tabular}{|c|c|c|c|c|c|c|c|}
\hline \multirow{2}{*}{$\begin{array}{c}\text { Nomor } \\
\text { Saringan }\end{array}$} & \multirow{2}{*}{$\begin{array}{l}\text { Ukuran } \\
\text { Ayakan } \\
(\mathrm{mm})\end{array}$} & \multicolumn{2}{|c|}{$\begin{array}{c}\text { \% Berat Yang Lolos } \\
\text { Terhadap Total Agregat dalam } \\
\text { Campuran AC-BC }\end{array}$} & \multicolumn{2}{|c|}{$\begin{array}{c}\text { \% Berat Yang } \\
\text { Tertahan Terhadap Total } \\
\text { Agregat dalam } \\
\text { Campuran AC-BC } \\
\end{array}$} & \multirow{2}{*}{$\begin{array}{c}\text { Berat } \\
\text { dalam } \\
\text { Campuran } \\
\text { (gr) }\end{array}$} & \multirow{2}{*}{$\begin{array}{l}\text { Komposisi } \\
\text { Campuran }\end{array}$} \\
\hline & & $\begin{array}{l}\text { Spesifikasi } \\
\text { Gradasi }\end{array}$ & $\begin{array}{l}\text { Rancangan } \\
\text { Gradasi } \\
\text { Campuran }\end{array}$ & $\begin{array}{l}\text { Proporsi } \\
(\%)\end{array}$ & $\begin{array}{l}\text { Proporsi } \\
\text { dalam } \\
\text { Campuran } \\
(\%)\end{array}$ & & \\
\hline $1 \frac{11 / 2}{2}$ & 37,5 & & & & & & $43 \%$ \\
\hline 1 & 25 & 100 & 100 & 5 & 4.5 & 54 & Agregar \\
\hline $3 / 4$ & 19 & $90-100$ & 95,5 & 12.5 & 12 & 144 & Kasar \\
\hline $1 / 2$ & 12,5 & $75-90$ & 82,5 & 8.5 & 18 & 96 & \\
\hline $3 / 8$ & 9,5 & $66-82$ & 74,0 & 19 & 18.5 & 222 & \\
\hline No. 4 & 4,75 & $46-64$ & 55,0 & 15.5 & 15 & 180 & \\
\hline No. 8 & 2,36 & $30-49$ & 39,5 & 11.5 & 11 & 132 & \\
\hline No. 16 & 1,18 & $18-38$ & 28,0 & 8 & 7.5 & 90 & \\
\hline No. 30 & 0,6 & $12-28$ & 20,0 & 6.5 & 6 & 72 & $46 \%$ \\
\hline No. 50 & 0,3 & $7-20$ & 13,5 & 4,5 & 4 & 48 & Agregat \\
\hline No. 100 & 0,15 & $5-13$ & 9,0 & 3 & 2.5 & 30 & Halus \\
\hline No. 200 & 0,075 & $4-8$ & 6,0 & 6 & 5.5 & 66 & \\
\hline Pan & & & 5.5 & & 5.5 & 66 & 5,5 \\
\hline
\end{tabular}

\section{Analisis Terhadap Stabilitas}

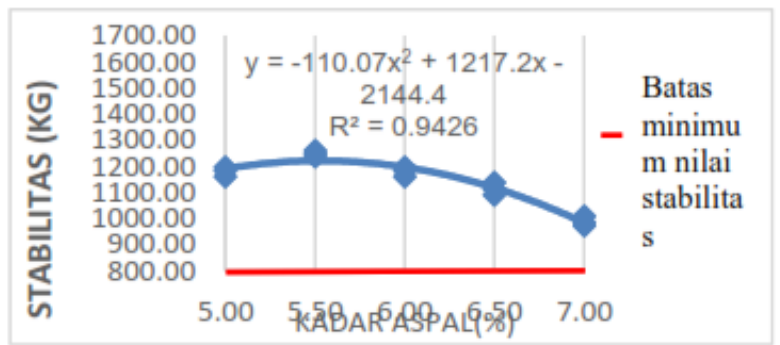

Gambar 3. Hubungan kadar aspal dan stabilitas
Nilai stabilitas menunjukkan nilai antara $971,68 \mathrm{~kg}$ sampai dengan $1259,58 \mathrm{~kg}$. Nilai tersebut memenuhi persyaratan. Dari nilai tersebut dibuatkan grafik hubungan antara nilai stabilitas dengan kadar aspal seperti pada gambar 3. Penggunaan kadar aspal yang sedikit dalam campuran AC-BC akan menghasilkan selimut aspal yang tipis pada permukaan agregat yang mengakibatkan ikatan antar agregat (Interlocking) menjadi lemah sehingga stabilitas campuran kecil, tetapi jika aspal bertambah lagi maka ikatan antar agregat menjadi kuat/stabilitas campuran besar.

Analisis Terhadap VIM (Void in Mix) 
Penggunaan kadar aspal 5,00\%-7,00\% diperoleh nilai VIM antara $4,49 \%-3,07 \%$. Nilai VIM ini memenuhi persyaratan. Semakin tinggi kadar aspal yang digunakan maka nilai VIM semakin kecil begitu pula sebaliknya, apabila kadar aspal yang digunakan semakin kecil maka nilai VIM akan semakin besar, hal ini kerena aspal berfungsi sebagai pengikat dan pengisi rongga di dalam campuran beraspal.

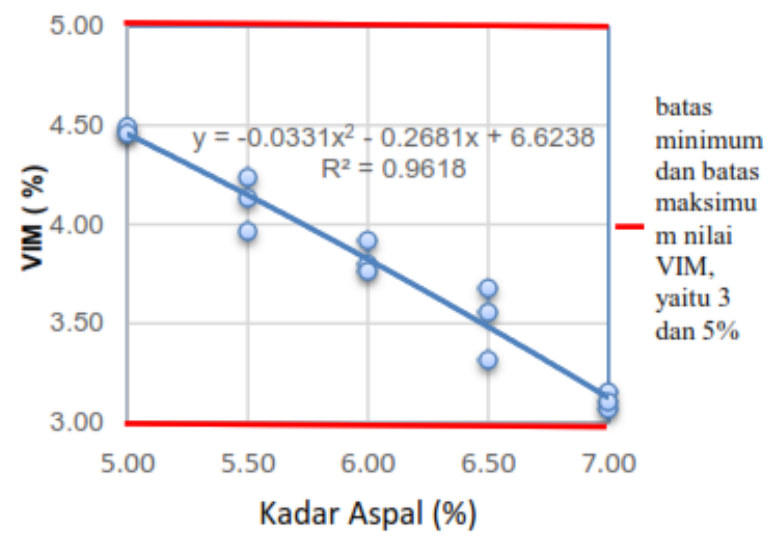

Gambar 4. Hubungan VIM terhadap kadar aspal Analisis Terhadap Flow

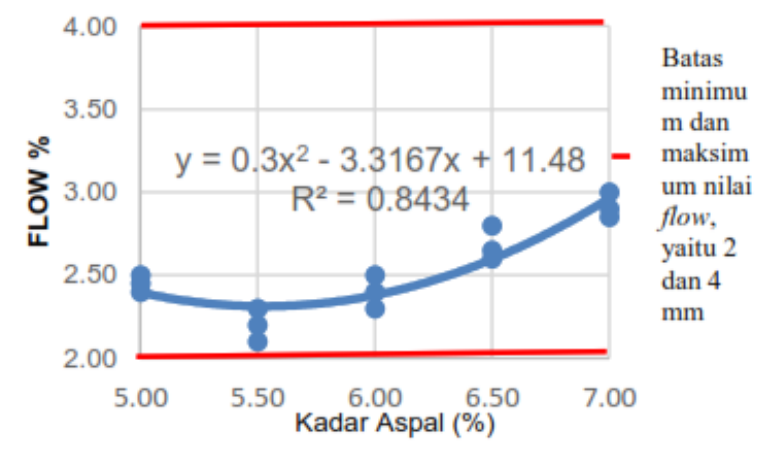

Gambar 5. Hubungan flow terhadap kadar aspal

Nilai flow dapat diketahui antara $3,17 \mathrm{~mm}$ sampai dengan $3,85 \mathrm{~mm}$. Nilai tersebut memenuhi persyaratan. jika penggunaan aspal dalam campuran beraspal kecil maka ikatan antar agregatnya berkurang yang menyebabkan kelelehan besar, kemudian jika penggunaan aspal bertambah lagi maka selimut aspal menjadi lebih tebal yang mengakibatkan kekuatan campuran berkurang tetapi kelelehan bertambah besar, yang artinya kekuatan campuran/stabilitas akan berbanding terbalik dengan kelelehan campuran atau flow.

\section{Analisis Terhadap VMA (Void in Mineral Aggregate)}

Dengan menggunakan kadar aspal 5,00\%-7,00\%. diperoleh nilai VMA antara $14,12 \%-17,69 \%$, seperti pada tabel 5 , dimana nilai tersebut memenuhi persyaratan. Hal ini dipengaruhi oleh semakin banyak aspal yang digunakan, oleh karena fungsi aspal selain menyelimuti agregat (aspal efektif) juga berfungsi untuk mengisi rongga diantara agregat dan dalam partikel agregat. Dari Gambar 6 dapat disimpulkan bahwa semakin banyak aspal yang di gunakan maka rongga dalam agregat yang terisi aspal semakin besar sehingga nilai VMA akan meningkat. Hal ini dipengaruhi oleh penggunaan aspal yang banyak dimana saat pencampuran dan pemadatan, aspal akan menyelimuti agregat, mengisi rongga diantara agregat dan mengisi rongga dalam agregat.

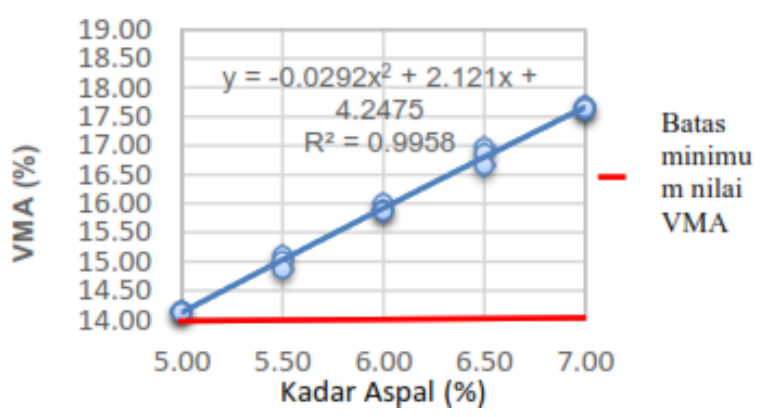

Gambar 6. Hubungan VMA terhadap kadar aspal Analisis Terhadap VFB (Void Filled With Bitument)

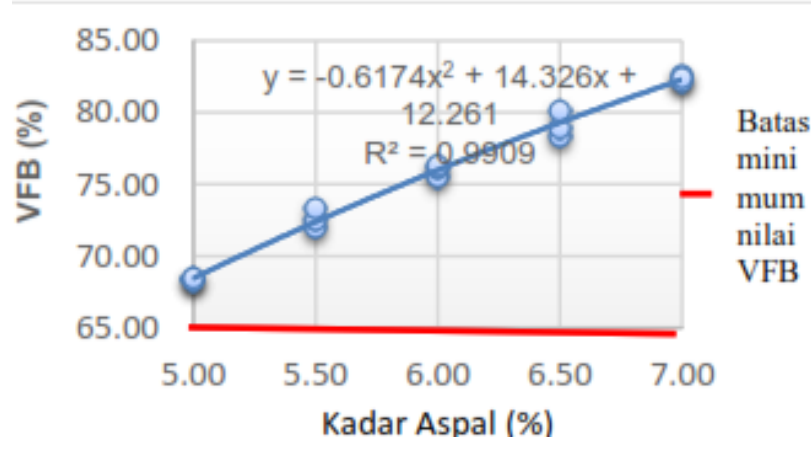

Gambar 7. Hubungan kadar aspal dan VFB

Semakin tinggi kadar aspal nilai VFB semakin meningkat. Ini memperlihatkan bahwa penggunaan kadar aspal yang sedikit mengurangi VFB, penggunaan kadar aspal yang banyak memperbesar VFB, begitu pun sebaliknya. Di mana aspal akan mengisi semua rongga yang ada dalam campuran dan dalam agregat.

\section{Penentuan Kadar Aspal Optimum}

Berdasarkan hasil analisis karakteristik campuran AC-BC dapat ditentukan kadar aspal praktis dalam campuran AC-BC yaitu kadar aspal yang memenuhi semua kriteria atau karakteristik campuran AC-BC dan kadar aspal praktis tersebut adalah rentang kadar aspal 5,00\% - 7,00\% untuk campuran ACBC. Namun untuk kadar aspal optimum maka pada campuran AC- BC dipilih yang memiliki stabilitas yang paling tinggi yaitu pada kadar aspal 5,5\% 
karena lapisan AC-BC merupakan lapisan binder atau lapisan penopang yang harus memberikan dukungan yang kuat bagi lapisan di atasnya.

Dari hasil pengujian Marshall Immersion diperoleh Stabilitas Marshall Sisa sebesar $97.68 \%$ untuk campuran AC-BC dengan kadar aspal $7.50 \%$. Nilai Stabilitas Marshall Sisa ini telah memenuhi standar yang ditetapkan oleh Spesifikasi Umum Bina Marga 2018 yaitu minimal 90\%. Berdasarkan nilai tersebut dapat disimpulkan bahwa perkerasan jalan yang menggunakan agregat Gunung Baba Kabupaten Tana Toraja dalam campuran AC-BC tahan terhadap suhu dan lamanya perendaman dalam air.

\section{KESIMPULAN}

Karakteristik agregat yang berasal dari Gunung Baba Kabupaten Tana Toraja, karakteristik aspal dan berat jenis filler untuk campuran AC-BC memenuhi Spesifikasi Umum Bina Marga 2018.

Berdasarkan rancangan komposisi campuran AC-BC yang menggunakan agregat Gunung Baba Kabupaten Tana Toraja diperoleh agregat kasar $36.75 \%$, agregat halus $50.00 \%$, filler $5.75 \%$ dengan kadar aspal optimum $7.50 \%$.

Berdasarkan hasil pengujian karakteristik campuran AC-BC melalui pengujian Marshall Konvensional diperoleh karakteristik campuran beraspal semua memenuhi spesifikasi yaitu stabilitas, flow, VIM, VMA, dan VFB yang dikeluarkan oleh Dirjen Bina Marga. Nilai Stabilitas Marshall Sisa dari hasil pengujian Marshall Immersion pada campuran AC-BC yang menggunakan agregat Gunung Baba Kabupaten Tana Toraja memenuhi Spesifikasi Umum Bina Marga 2018 Divisi 6, yaitu 97.68\% > 90\%.

\section{DAFTAR PUSTAKA}

[1] M. D. M. Palinggi dan Elizabeth, 2020, "Utilization of Lightweight Brick Waste Material As a Mixture of Laston AC-WC." J. of Physics Conference Series 1464:012049, doi:10.1088/1742-6596/1464/1/012049.

[2] N. Wendani, M. Selintung, dan Alpius, 2020, "Studi Penggunaan Agregat Sungai Bittuang Sebagai Bahan Campuran AC-WC" Paulus Civil Engineering Journal, Vol.2, No.2.
[3] I. S. K. Sosang, Alpius, dan Elizabeth, 2020, "Pemanfaatan Agregat Sungai Mawa Kecamatan Cendana Dalam Campuran AC-WC" Paulus Civil Engineering Journal Vol.2, No.1.

[4] S. A. Datu, R. Rachman, dan M. Selintung, 2020, "The Effect of Additional Sugar Palm Fibres on The Durability of Mixed Laston AC-WC." IOP Conference Series Earth and Environ Sci.

[5] I. M. Batara, R. Mangontan, dan Alpius, 2020 "Pemanfaatan Agregat Sungai Lamasi Kabupaten Luwu Sebagai Campuran Lapisan Aspal Beton AC-WC" Paulus Civil Engineering Journal Vol.2, No.3

[6] A. Asrol, S. M. Saleh, dan M. Isya, 2018, "Karakteristik Campuran Aspal Beton AC-WC dengan Substitusi Buton Rock Asphalt Terhadap Rendaman Air Lumpur" J. Arsip Rekayasa Sipil Perencanaan, vol. 1, no. 3, doi: 10.24815/jarsp.v1i3.11760.

[7] S. Yuniarti, R. Rachman, dan Alpius, 2020, "Studi Karakteristik Campuran AC-BC Berdasarkan Limbah Kantong Plastik Sebagai Bahan Tambah", Paulus Civil Engineering Journal, vol. 2, no.2, hlm.70-76.

[8] G. P. Palimbunga, R. Rachman, dan Alpius, 2020, "Penggunaan Agregat Sungai Batu Tiakka' pada Campuran AC-BC, Paulus Civil Engineering Journal, vol.2, no.2, hlm. 112-118

[9] G. Yanti, S. H. Megasari, dan H. Rahmat, 2017, "Karakteristik Marshall Pada Campuran AC-BC Dengan Penambahan Bahan Pengisi (Filler) Fly Ash", RACIC Journal Rab Construction Research, vol.2, no.1, hlm.158-165.

[10] R. Rachman, 2020, "Pemanfaatan Batu Gunung Bottomale Toraja Utara Sebagai Campuran Laston", J. Teknik Sipil dan Teknologi Konstruksi, vol.6, no.1, doi: https://doi.org/10.35308/jts-utu.v6i1.2307 